\title{
Levels and potential health hazards of PCBs in shallow groundwater of an e-waste recycling area, China
}

\author{
Chunfa $\mathrm{Wu}^{1} \cdot \mathrm{Hao} \mathrm{Zhu}^{1} \cdot$ Yongming $\mathrm{Luo}^{2} \cdot$ Ying Teng $^{3} \cdot$ Jing Song $^{3} \cdot$ \\ Mengfang Chen ${ }^{3}$
}

Received: 9 August 2014/Accepted: 15 April 2015/Published online: 17 May 2015

(C) Springer-Verlag Berlin Heidelberg 2015

\begin{abstract}
The improper disassembly of polychlorinated biphenyl (PCB)-containing equipments such as capacitor and electrical transformer can lead to PCB pollution. To investigate the levels and patterns of PCBs in shallow groundwater in regions where PCB-containing equipment is disassembled, 19 shallow groundwater samples were collected from a recycling area for waste capacitors and electrical transformers in southeastern China. The $\Sigma 21$ PCBs in shallow groundwater had a large variation ranging from 6.22 to $97.3 \mathrm{ng} \mathrm{L}^{-1}$, with a mean of $31.6 \mathrm{ng} \mathrm{L}^{-1}$ and low chlorinated PCBs (3-5 chlorinated biphenyls) were predominant homologs in majority groundwater samples. The United States Environmental Protection Agency (US EPA) toxic equivalents of 6 shallow groundwater samples with detectable dioxin-like PCBs varied greatly from 0.29 to $650 \mathrm{pg} \mathrm{L}^{-1}$, and all of them posing serious cancer risk $\left(>1 \times 10^{-6}\right)$ to children and adults. Much attention should be paid to the vertical migration of low chlorinated PCBs and the cancer risk of dioxin-like PCBs in the study area and similar e-waste recycling areas.
\end{abstract}

Keywords Polychlorinated biphenyls - E-waste . Composition · Toxic equivalent $\cdot$ Health risk

Chunfa Wu

wchf1680@sina.com

1 Nanjing University of Information Science and Technology, 210044 Nanjing, China

2 Yantai Institute of Coastal Zone Research, Chinese Academy of Sciences, 264003 Yantai, China

3 Key Laboratory of Soil Environment and Pollution Remediation, Institute of Soil Science, Chinese Academy of Sciences, 71 East Beijing Rd, 210008 Nanjing, China

\author{
Abbreviations \\ PCBs Polychlorinated biphenyls \\ POPs Persistent organic pollutants \\ US EPA United States Environmental Protection \\ Agency \\ PVC Polyvinyl chloride \\ min Minute \\ MDLs Method detection limits \\ RSD Relative standard deviation \\ TCDD Tetrachlorodibenzo-p-dioxin \\ TEFs Toxic equivalency factors \\ TEQs Toxic equivalents \\ 57I-PCBs Total concentrations of the 7 indicator PCB \\ congeners \\ इ21PCBs Total concentrations of the 21 PCB congeners
}

\section{Introduction}

Polychlorinated biphenyls (PCBs) are typical persistent organic pollutants (POPs) which are highly toxic and bioaccumulative in the environment (Halsall et al. 1995; Wang et al. 2008) and their persistence in the environment has been a growing concern. PCBs have been shown to have toxic effects on various organs including tissues of the nervous, reproductive, and immunologic systems (Buck et al. 2000; Hennig et al. 2002; Tan et al. 2003, 2004; Bemis and Seegal 2004). In general, the toxicological effects of PCBs vary at the congener level (Safe 1992) and PCBs become more toxic with increasing chlorine content (Tanabe 1988). Thus, it is necessary to know the levels and patterns of PCBs in environmental media in risk assessment of PCBs. 
PCBs had been widely used for industrial and commercial purposes such as dielectric fluids in capacitors and transformers; additives in pesticides, carbonless copy paper, paints, adhesives, and sealants; hydraulic and heattransfer fluids; and lubricating and cutting oils due to their good insulating properties and lack of appreciable degradation over time or with exposure to high temperatures (Erickson 1997; Menad et al. 1998; Leung et al. 2006). It was reported that the cumulative global production of commercial PCBs is approximately 1.3 million ton (Breivik et al. 2002). In China, approximately 10, 000 tons of PCBs were produced from 1965 to 1974 (China SEPA 2003). Of the 10,000 tons of PCBs, about 9000 tons were trichlorobiphenyl and 1000 tons were pentachlorobiphenyl (Xing et al. 2005). The trichlorobiphenyl was mainly used for capacitors' production and pentachlorobiphenyl mainly as additives in pigment (China SEPA 2003). Due to the toxicity and classification of $\mathrm{PCBs}$ as persistent organic pollutants, PCB production was banned by the government of the People's Republic of China in 1974 and by the Stockholm Convention on Persistent Organic Pollutants in 2001. However, PCBs are still present in many pre-1974 domestic products and numerous electrical transformers and capacitors containing PCBs from Belgium and France (Zhang et al. 2007). Many of these PCB products including electrical transformers and capacitors were abandoned and became hazardous wastes. Due to technology and financial constraints, a large proportion of waste PCB products were not disposed of properly in China. PCBs can be released from commercial PCB products via waste emissions, oil leakage, volatilization, dry and wet deposition, etc., which are the potential primary sources of PCBs in the environment (Herrick et al. 2007).

Due to their toxic effects in both humans and wildlife e (Cogliano 1998; Giesy and Kannan 1998), the levels and distributions of PCBs have aroused great concerns of environmental health. It is well known that PCBs have low aqueous solubility and low vapor pressures at room temperature, but they have high solubility in most organic solvents, oils, and fats. PCBs can leach from surface soil to underlying aquifers with organic solvents and pose potential risk to shallow groundwater in areas heavily polluted with PCBs. In China, a number of studies have been conducted on the pollution of PCBs in environmental media such as atmosphere (Bi et al. 2002; Lammel et al. 2007), sediments (Zhou et al. 2001; Mai et al. 2005; Fu and Wu 2006), and surface water (Wang et al. 2003; Zhang et al. 2003; He et al. 2006; Dai et al. 2011). To date, however, studies on PCBs in shallow groundwater are rare. Reports showed PCB pollution in some e-waste recycling areas in China due to the disassembly of PCB-containing equipment such as electrical transformers and capacitors which contained PCB solution, organic solvents, and oils (Chu et al. 1995; Bi et al. 2002; Zhang et al. 2009). The general objectives of this study were to (1) investigate the levels and patterns of PCBs in shallow groundwater in a recycling area for waste capacitors and electrical transformers in southeastern China, (2) to assess the overall toxicity of the dioxin-like PCBs in the shallow groundwater.

\section{Materials and methods}

\section{Description of study area}

The study area is a typical waste capacitors and electrical transformers recycling area in Taizhou city, Zhejiang Province, southeastern China with a total area of approximately $22.74 \mathrm{~km}^{2}$. In the study area, there are many family-operated recycling facilities to process a large quantity of e-wastes including capacitors and electrical transformers which contained PCB solution from domestic supplies and developed countries since the late 1980s. Previous studies showed that the topsoil, surface water, sediments, and atmosphere in the study area were heavily polluted by PCBs (Bi et al. 2002; Zhang et al. 2009; Han et al. 2010). Two recycling industrial parks have been established in southeastern of the study area with purpose of promoting efficient and environmentally friendly recovery of original and imported metal scraps (Fig. 1), and most of e-waste recycling activities were carried on in the industrial park in recent years. The study area has become an important e-waste recycling area in southeastern China.

The study area is in the northern subtropical zone of monsoonal climate with a temperate and humid climate throughout the year with four distinct seasons. The average annual temperature is $17.1{ }^{\circ} \mathrm{C}$ and the mean annual precipitation is approximately $1523 \mathrm{~mm}$. Cropland and woodland are two major agricultural land use types; industrial land and residential land are two major non-agricultural land use types in the study area. Gleysols is the major type of anthropogenic soils in the study area. According to hydrogeological data, the thickness of the porous unconfined aquifer is approximately $2-3 \mathrm{~m}$, and the shallow groundwater level is approximately $0.5-2.5 \mathrm{~m}$ being deeper in the west and more shallow in the eastern region of the study area. The permeability of the unconfined aquifer was uneven and very low. The vertical flow is the major movement of groundwater and the velocity of horizontal flow was very low due to the small hydraulic gradient in the study area. Shallow groundwater is an important source of drinking water in the study area because of the poor water quality of the surface waters. 


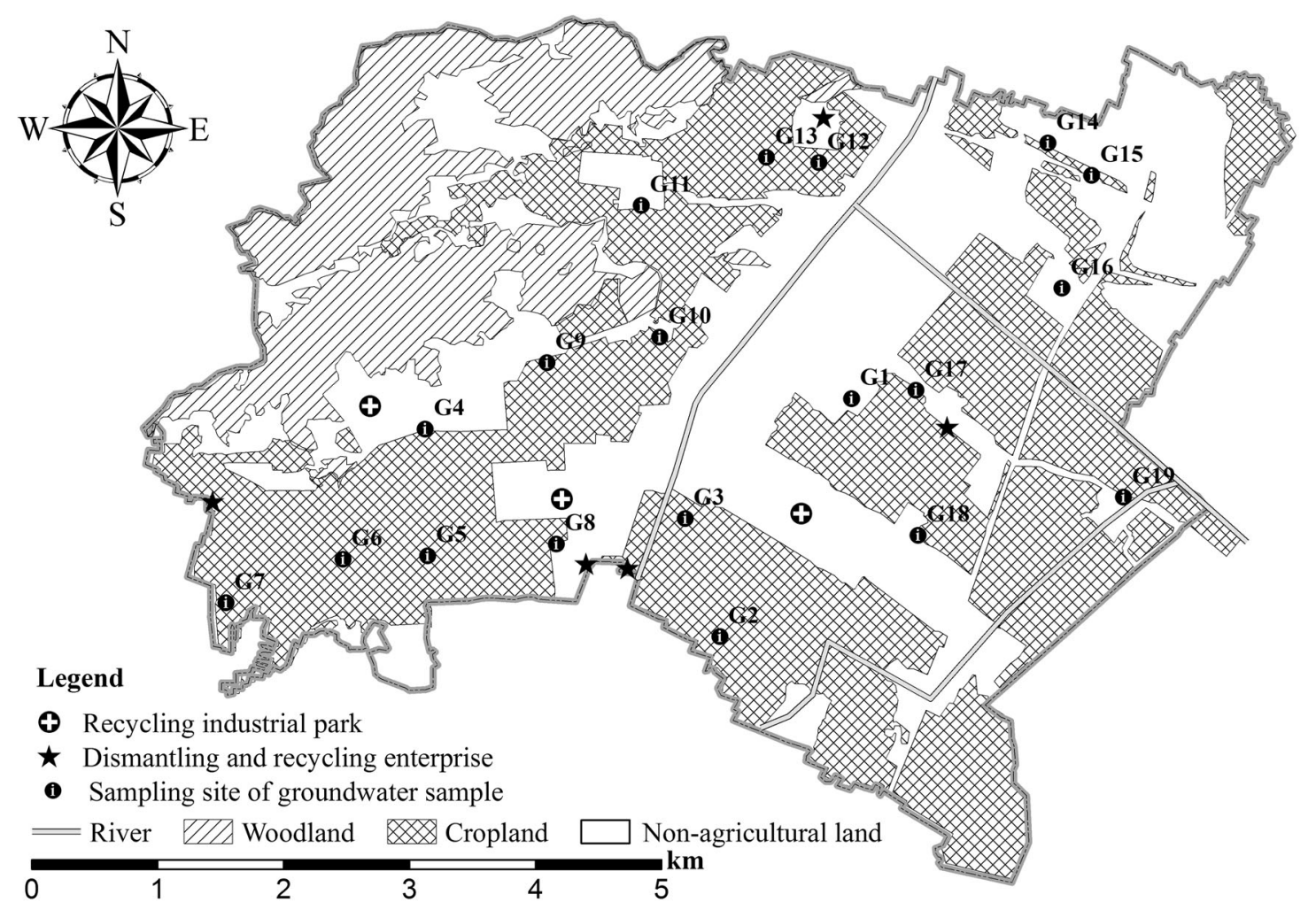

Fig. 1 The distribution of sampling sites in study area

\section{Groundwater sampling}

19 shallow groundwater samples were collected from monitoring wells with consideration of uniform distribution and pollution source in December 2009 (Fig. 1). The groundwater levels during sampling were about $0.5-0.7 \mathrm{~m}$ below the ground surface. Groundwater samples were collected following this sequence: (1) pumping the tube well until the electrical conductivity and $\mathrm{pH}$ remain stable; (2) washing out a clean brown glass bottle with the groundwater; (3) collecting groundwater from $5 \mathrm{~cm}$ below the groundwater table using polyvinyl chloride (PVC) Baylor tube and filtering the water through a $0.45-\mu \mathrm{m}$ glass fiber filter (Whatman, Clifton, NJ, USA); (4) filling a 1-L brown bottle with filtered groundwater and acidifying with ultrapure sulfuric acid to $\mathrm{pH}<2$; (5) sealing the bottle using polytetrafluoroethylene membrane and storing the sample at $4{ }^{\circ} \mathrm{C}$.

\section{Sample extraction and cleanup}

The "dissolved PCBs" in the shallow groundwater samples were obtained by continuous liquid-liquid extraction three times using resteamed hexane. The extract was transferred to an eggplant-shaped flask and dried with a rotary evaporator. The residue was dissolved in 5-10 $\mathrm{ml}$ distilled hexane and purified by a column that is filled with silica gel, neutral alumina, acidic silica gel, and anhydrous sodium sulfate at a ratio of 2:2:1:1 to eliminate the interference of organochlorine pesticides and lipid. The purified solution was dried and dissolved in $1 \mathrm{ml}$ chromatographygrade pure hexane.

\section{PCB analysis and quality control}

A Hewlett-Packard $6890 \mathrm{GC}$ system equipped with a ${ }^{63} \mathrm{Ni}$ electron capture detector- $\mu \mathrm{ECD}$ (Agilent Technology Co., USA) was used to perform the gas chromatographic analysis using the splitless mode. Chromatographic separation of the PCB congeners (PCB8, PCB18, PCB28, PCB44, PCB52, PCB66, PCB77, PCB101, PCB105, PCB118, PCB126, PCB128, PCB138, PCB153, PCB170, PCB180, PCB187, PCB195, PCB200, PCB206, PCB209) was achieved using a CP-sil24CB column $(30 \mathrm{~m} \times 0.25 \mathrm{~mm}$ $\times 0.25 \mu \mathrm{m})($ Varian Associates, USA). The injector and the detector were set at 270 and $300{ }^{\circ} \mathrm{C}$, respectively, and the split ratio was set at 30 . The oven temperature was set up at $180{ }^{\circ} \mathrm{C}$ for $0.5 \mathrm{~min}$ (min), from 180 to $260{ }^{\circ} \mathrm{C}$ at $30{ }^{\circ} \mathrm{C} \mathrm{min}{ }^{-1}$, kept at $270{ }^{\circ} \mathrm{C}$ for $22 \mathrm{~min}$, from 260 to $270{ }^{\circ} \mathrm{C}$ at $15{ }^{\circ} \mathrm{C} \mathrm{min}{ }^{-1}$, with a final hold of $8 \mathrm{~min}$. The chromatographs were recorded and analyzed using HP ChemStation software. The quantification was done using external standard calibration curve method according to the US EPA method 8000b. 
The method detection limit (MDL) was defined as the mean plus three times the signal/noise of the method blanks. The MDLs for the PCB congeners ranged from 1.4 to $5.1 \mathrm{ng} \mathrm{L}^{-1}$. The mixed standards with $10 \mathrm{ml}$ of $0.5 \mu \mathrm{g} \mathrm{L}^{-1}$ diluted mixed standard of the 21 PCB congeners were spiked into the groundwater before extraction for assessment of recovery rates and three replicates were measured for each PCB congener. The average percent recovery and respective relative standard deviation (RSD) for the individual selected PCB congeners varied from 83.2 to $97.4 \%$ and from 1.2 to $5.5 \%$, respectively.

\section{Toxic equivalents' calculation and health risk assessment model}

It is well known that some of PCBs are structurally and chemically similar to 2,3,7,8-tetrachlorodibenzo-p-dioxin (2,3,7,8-TCDD), and are known to act in a similar way to produce toxicity in humans. These PCB congeners are the so-called dioxin-like PCBs. Although all dioxin-like PCBs are thought to act in the same way, they are not all equally toxic and their toxicity varies considerably (van den Berg et al. 2006). Because PCBs are almost invariably found in complex mixtures, the concept of toxic equivalency factors (TEFs) has been developed to compare the relative toxicity of the other dioxin-like compounds to that of 2,3,7,8TCDD and to facilitate risk assessment and regulatory control. World Health Organization-recommended TEFs for humans of the 12 dioxin-like PCBs are listed in the Table 1 (van den Berg et al. 2006). The overall toxicity of a mixture of these dioxin-like compounds is commonly expressed as a single number, the toxic equivalents (TEQs), obtained by summing individual compounds concentrations weighed by TEF. To assess the overall toxicity of the dioxin-like PCBs in the shallow groundwater, the TEQs of 19 shallow groundwater samples in the study area were calculated as follows:

TEQs $=\Sigma\left(\mathrm{TEF} \times C_{\mathrm{G}}\right)$

Table 1 United States Environmental Protection Agency (US EPA) toxic equivalency factor (TEF) values for the 12 dioxin-like polychlorinated biphenyls (PCBs) to that of 2,3,7,8-tetrachlorodibenzo-pdioxin $(2,3,7,8$-TCDD)

\begin{tabular}{llll}
\hline PCB congener & TEF & PCB congener & TEF \\
\hline PCB 77 & 0.0001 & PCB 81 & 0.0003 \\
PCB 105 & 0.00003 & PCB 114 & 0.00003 \\
PCB 118 & 0.00003 & PCB 123 & 0.00003 \\
PCB 126 & 0.1 & PCB 156 & 0.00003 \\
PCB 167 & 0.00003 & PCB 157 & 0.00003 \\
PCB 169 & 0.03 & PCB 189 & 0.00003 \\
\hline
\end{tabular}

where $C_{\mathrm{G}}$ is the concentration of dioxin-like PCBs in shallow groundwater.

Health risk assessment is the process to estimate the nature and probability of adverse health effects in humans who may be exposed to chemicals in contaminated environmental media, now or in the future. In this study, a health risk assessment model derived from United States Environmental Protection Agency (US EPA) is applied to estimate the carcinogenic risks for adults and children consuming the shallow groundwater as their drinking water source (US EPA 2005). The chronic daily intake (CDI) is used to estimate human exposure to contaminants (US EPA 1989), and is calculated using the following formula.

$\mathrm{CDI}=\frac{C \times \mathrm{IR} \times \mathrm{EF} \times \mathrm{ED}}{\mathrm{BW} \times \mathrm{AT}}$,

where $C$ is the chemical concentration in water $\left(\mathrm{mg} \mathrm{L}^{-1}\right)$; IR the water ingestion rate $\left(\mathrm{L} \mathrm{day}^{-1}\right.$ ) (for children: $\mathrm{IR}=1.0$; for adults: $\mathrm{IR}=2.0$ ); EF the exposure frequency (350 days year ${ }^{-1}$ ); ED the exposure duration (year) (for children: $\mathrm{ED}=6$; for adults: $\mathrm{ED}=70)$; $\mathrm{BW}$ the body weight (kg) (for children: $\mathrm{BW}=14$; for adults: $\mathrm{BW}=60$ ); and AT the average lifespan (days) (for children: $\mathrm{AT}=2190$; for adults: $\mathrm{AT}=25,550)$.

From the US EPA exposure factors handbook (US EPA 1997), carcinogenic risk $(R)$ is calculated as follows:

$R=\mathrm{CDI} \times \mathrm{SF}$,

where CDI is the chronic daily intake from the oral exposure route $\left(\mathrm{mg} \mathrm{kg}^{-1} \mathrm{day}^{-1}\right.$ ), and $\mathrm{SF}$ the slope factor of the contaminant via oral exposure route $\left[\left(\mathrm{mg} \mathrm{kg}^{-1} \mathrm{day}^{-1}\right)^{-1}\right]$.

\section{Results and discussion}

\section{Concentrations of indicator PCBs in shallow groundwater}

The total concentrations of the 21 PCB congeners ( $\Sigma 21 \mathrm{PCBs}$ ) in shallow groundwater varied greatly from 6.22 to $97.3 \mathrm{ng} \mathrm{L}^{-1}$, with a mean of $31.6 \mathrm{ng} \mathrm{L}^{-1}$ (Table 2). The levels of PCBs in shallow groundwater in the study area were higher than that of in groundwater of Nanshan underground River, China (Jahangir et al. 2013), and those of in surface water of Baikal Lake, Russia (Iwata et al. 1995), Lake Michigan, USA(Pearson et al. 1996) and Xiamen Harbor, China (Zhou et al. 2000), but were lower than that in surface water of Minjiang River, China (Zhang et al. 2003) (Table 3). Among the 21 PCB congeners, the detectable ratios of PCB18 (2,2',5-Trichlorobiphenyl) and

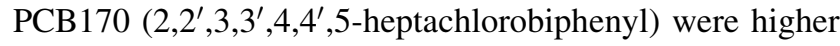
than other congeners, and they accounted for 44.5 and $34.3 \%$ of $\Sigma 21 \mathrm{PCBs}$, respectively. It demonstrated that 
Table 2 Total concentrations $(\Sigma)$, toxic equivalents (TEQs) and total carcinogenic risk of polychlorinated biphenyls (PCBs) in shallow groundwater samples
Table 3 Total concentrations of polychlorinated biphenyls ( $\Sigma$ PCBs, ng L ${ }^{-1}$ ) in groundwater and surface water around the world

\begin{tabular}{|c|c|c|c|c|c|}
\hline \multirow[t]{2}{*}{ Sample ID } & \multirow[t]{2}{*}{$\Sigma 7 \mathrm{I}-\mathrm{PCBs}\left(\mathrm{ng} \mathrm{L}^{-1}\right)$} & \multirow[t]{2}{*}{$\Sigma 21 \mathrm{PCBs}\left(\mathrm{ng} \mathrm{L}^{-1}\right)$} & \multirow[t]{2}{*}{ TEQs $\left(\mathrm{pg} \mathrm{L}^{-1}\right)$} & \multicolumn{2}{|c|}{ Carcinogenic risk $\left(10^{-6}\right)$} \\
\hline & & & & Adults & Children \\
\hline LQ-1 & nd & 9.85 & 0 & 0 & 0 \\
\hline LQ-2 & nd & 33.03 & 0.41 & 2.0 & 4.2 \\
\hline LQ-3 & nd & 18.01 & 0 & 0 & 0 \\
\hline LQ-4 & nd & 11.28 & 0 & 0 & 0 \\
\hline LQ-5 & 2.73 & 43.19 & 0.29 & 1.4 & 3.0 \\
\hline LQ-6 & nd & 13.67 & 0 & 0 & 0 \\
\hline LQ-7 & nd & 14.17 & 0 & 0 & 0 \\
\hline LQ-8 & nd & 48.23 & 0 & 0 & 0 \\
\hline LQ-9 & nd & 40.74 & 0 & 0 & 0 \\
\hline LQ-10 & 21.37 & 31.27 & 0 & 0 & 0 \\
\hline LQ-11 & 17.32 & 81.04 & 399 & 1913 & 4099 \\
\hline LQ-12 & nd & 8.14 & 0 & 0 & 0 \\
\hline LQ-13 & nd & 97.30 & 0.72 & 3.5 & 7.4 \\
\hline LQ-14 & nd & 43.98 & 0.36 & 1.7 & 3.7 \\
\hline LQ-15 & nd & 10.62 & 0 & 0 & 0 \\
\hline LQ-16 & nd & 6.22 & 0 & 0 & 0 \\
\hline LQ-17 & nd & 13.01 & 0 & 0 & 0 \\
\hline LQ-18 & 12.49 & 36.41 & 650 & 3116 & 6678 \\
\hline LQ-19 & 6.59 & 40.37 & 0 & 0 & 0 \\
\hline
\end{tabular}

$\Sigma 7 I-P A H s$ the total concentrations of the 7 indicator PCB congeners in shallow groundwater, $\Sigma 21 P A H s$ the total concentrations of the $21 \mathrm{PCB}$ congeners in shallow groundwater, TEQs the toxic equivalents of all individual dioxin-like PCBs to that of 2,3,7,8-tetrachlorodibenzo-p-dioxin (2,3,7,8-TCDD), $n d$ not detected

\begin{tabular}{lllrl}
\hline Location & Year & Water type & \multicolumn{1}{c}{$\Sigma$ PCBs } & References \\
\hline E-waste recycling area, China & 2009 & Groundwater & $6.22-97.3$ & This study \\
Nanshan underground River, China & $2011-2012$ & Groundwater & $0.3-29.9$ & Jahangir et al. (2013) \\
Baiyangdian Lake, China & 2008 & Surface water & $19.46-131.62$ & Dai et al. (2011) \\
Minjiang River, China & 1999 & Surface water & 203.9-2473 & Zhang et al. (2003) \\
Baikal Lake, Russia & 1992 & Surface water & $0.018-0.59$ & Iwata et al. (1995) \\
Lake Michigan, USA & 1991 & Surface water & $0.34-1.74$ & Pearson et al. (1996) \\
\hline
\end{tabular}

PCB18 and PCB170 were the two major PCB congeners in shallow groundwater. In general, the seven indicator $\mathrm{PCB}$ congeners (PCB28, PCB52, PCB101, PCB118, PCB138, PCB153, PCB180) were commonly measured in PCB analysis and their concentrations are often used for comparison. In the study area, the concentrations of three indicator PCB congeners (PCB118, PCB138 and PCB180) were below their detection limits and the remaining 4 indicator PCB congeners had a low-moderate detectable ratio (5.26-21.1\%). It may be due to low water solubility and high affinity for adsorption to soil particles. In the study area, only five shallow groundwater samples had detected the indicator PCBs, and the total concentrations of the 7 indicator PCB congeners ( $\Sigma 7 \mathrm{I}-\mathrm{PCBs})$ in the five shallow groundwater samples varied greatly from 2.73 to $21.37 \mathrm{ng} \mathrm{L}^{-1}$, with a mean of $12.1 \mathrm{ng} \mathrm{L}^{-1}$ (Table 2). In the 7 indicator PCB congeners, PCB52 in the shallow groundwater had a relatively high detectable ratio and concentration.

\section{Composition of PCBs in shallow groundwater}

PCBs are a class of organic compounds with 1-10 chlorine atoms attached to biphenyl and the water solubility and vapor pressure of PCB congener decrease with increasing degree of chlorination (Ma et al. 2007). The composition of PCBs in the shallow groundwater is determined by a number of factors, which include chemical and physical properties of PCB congeners, the properties of aquifer, the influence of human activities, and so on. From Fig. 2, we could find that, low chlorinated PCBs (3-5 chlorinated biphenyls) were predominant homologs in majority 
Fig. 2 The pie chart of polychlorinated biphenyls' (PCBs') patterns in the 19 shallow groundwater samples in the study area

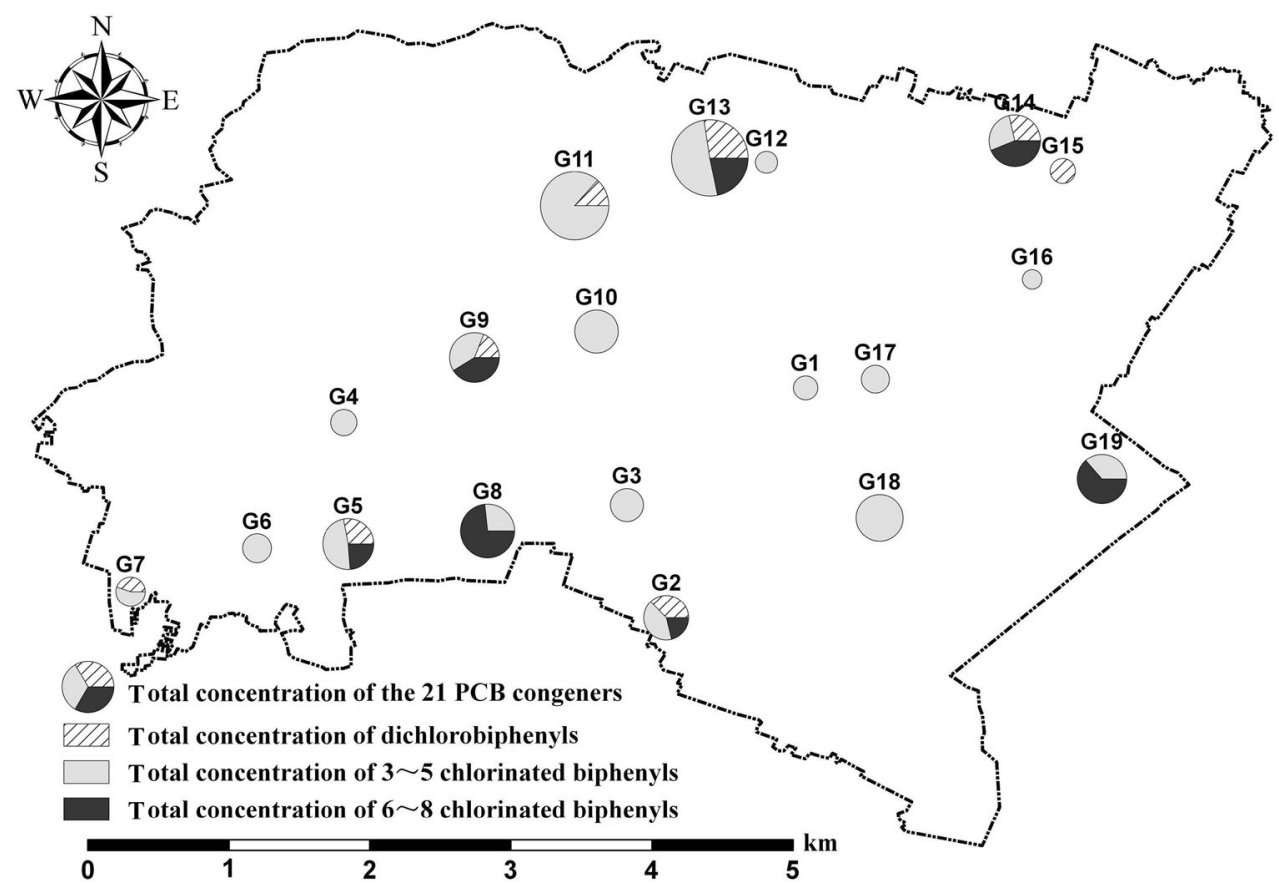

groundwater samples, consisting with their dominant global production. It is also consistent with the result of previous studies that 3-5 chlorinated biphenyls were the primary homologs in the topsoil and the atmosphere of the study area (Zhang et al. 2009; Han et al. 2010). According to relevant reports and our investigation, leakage of organic solvents and oils existed in the process of waste capacitors and electrical transformers disassembling in the study area (Chu et al. 1995; Bi et al. 2002). The high concentrations of high chlorinated PCBs in the several groundwater samples may be correlated with their low volatility, and leakage of organic solvents and oils. Considerable attention should be paid to the migration of low chlorinated PCBs in topsoil to shallow groundwater.

\section{Toxic equivalents and health risk of dioxin-like PCBs}

Of the 12 dioxin-like PCBs, 4 dioxin-like PCBs (PCB77, PCB105, PCB118, PCB126) were measured in this study. The detectable ratio of the 4 dioxin-like PCBs in the shallow groundwater of the study area was PCB77, $5.26 \%$; PCB105, $26.3 \%$; PCB118, 0; PCB126, $10.52 \%$, respectively. In this study, the TEQs to 2,3,7,8-TCDD were used to assess the overall toxicity of the dioxin-like PCBs in shallow groundwater. Due to large differences in composition of dioxin-like PCBs and TEFs, the TEQs to 2,3,7,8TCDD of $6(31.6 \%)$ shallow groundwater samples with detectable dioxin-like PCBs varied greatly from 0.29 to $650 \mathrm{pg} \mathrm{L}^{-1}$ (Table 2).
Dioxin-like PCBs generally are among the most toxic congeners, and they were also classified as carcinogenic to humans (Group 1) by the International Agency for Research on Cancer in 2013. The shallow groundwater is an important source of drinking water in the study area. So, it was necessary to study the cancer risk of dioxin-like PCBs in the shallow groundwater. Due to lack of relevant parameters (slope factor and reference dose) for each dioxinlike PCB congener, the total cancer risk caused by dioxinlike PCBs were calculated through the TEQs to 2,3,7,8TCDD. In this study, $1.5 \times 10^{5}\left(\mathrm{mg} \mathrm{kg}^{-1} \text { per day }\right)^{-1}$ was adopted as the value of SF for 2,3,7,8-TCDD in cancer risk calculation according to US EPA recommendation (US EPA 1985). Due to the TEQs to 2,3,7,8-TCDD of these shallow groundwater samples with detectable dioxin-like PCBs had a wide range, the total cancer risk level caused by dioxin-like PCBs for adults and children through drinking local shallow groundwater with detectable dioxinlike PCBs varied greatly from $1.4 \times 10^{-6}$ to $3.1 \times 10^{-3}$ for adults and from $3.0 \times 10^{-6}$ to $6.7 \times 10^{-3}$ for children. To all the shallow groundwater samples with detectable dioxin-like PCBs, cancer risk caused by dioxin-like PCBs either for children or for adults through drinking was greater than the acceptable risk level $\left(1 \times 10^{-6}\right)$ recommended by USEPA for carcinogens, respectively. It indicated that the current levels of dioxin-like PCBs in the shallow groundwater in partial area of study area posed serious cancer risk to the local population, especially to children, and the shallow groundwater in partial area of study area was not suitable for drinking water. 


\section{Conclusions}

The $\Sigma 21$ PCBs in shallow groundwater had a large variation ranging from 6.22 to $97.3 \mathrm{ng} \mathrm{L}^{-1}$ and they also vary from different sampling points. Low chlorinated PCBs (3-5 chlorinated biphenyls) were predominant homologs in majority groundwater samples, and high chlorinated PCBs (6-8 chlorinated biphenyls) were predominant homologs in several groundwater samples. It demonstrated that the patterns of PCBs in the shallow groundwater in the study area had some differences, and the cause need to further study.

Dioxin-like PCBs were detected in 6 (31.6\%) shallow groundwater samples of the study area, and these shallow groundwater samples had a wide range of TEQs to 2,3,7,8TCDD, $0.29-650 \mathrm{pg} \mathrm{L}^{-1}$ with serious cancer risks to children and adults $\left(>10^{-6}\right)$. Action is urgently required to mitigate and even control the vertical migration of PCBs, especially dioxin-like PCBs to decrease the health risk to shallow groundwater.

Acknowledgments This research was funded in part by the Project supported by the Key Laboratory of Soil Environment and Pollution Remediation and the Environmental Protection Commonwealth Industry Research Special Project (Grant No. 201109017-1). We appreciate the contribution of our colleagues who collected and analyzed the soil samples.

\section{References}

Bemis JC, Seegal RF (2004) PCB-induced inhibition of the vesicular monoamine transporter predicts reductions in synaptosomal dopamine content. Toxicol Sci 80:288-295

Bi X, Chu S, Meng Q, Xu X (2002) Movement and retention of polychlorinated biphenyls in a paddy field of WenTai area in China. Agriculture Ecosyst Environ 89:241-252

Breivik K, Sweetman A, Pacyna JM, Jones KC (2002) Towards a global historical emission inventory for selected PCB congeners - a mass balance approach I. Global production and consumption. Sci Total Environ 290:181-198

Buck GM, Vena JE, Schisterman EF, Dmochowski J, Mendola P, Sever LE, Fitzgerald E, Kostyniak P, Greizerstein H, Olson J (2000) Parental consumption of contaminated sport fish from Lake Ontario and predicted fecundability. Epidemiology 11:388-393

China SEPA (State Environmental Protection Administration) (2003) Building the capacity of the People's Republic of China to implement the Stockholm convention on POPs and develop a National implementation plan, GEF Project Brief (GF/CPR/02/ 010)

Chu SG, Yang C, Xu XB, Liu XX (1995) Polychlorinated biphenyl congener residues in sediment and soil from pollution area (in Chinese). China Environ Sci 15:199-203

Cogliano VJ (1998) Assessing the cancer risk from environmental PCBs. Environ Health Persp 106:317-323

Dai GH, Liu XH, Liang G, Han X, Shi L, Cheng DM, Gong WW (2011) Distribution of organochlorine pesticides (OCPs) and polychlorinated biphenyls (PCBs) in surface water and sediments from Baiyangdian Lake in North China. J Environ Sci (China) 23:1640-1649
Erickson MD (1997) Analytical Chemistry of PCBs, 2nd edn. CRC Press Inc, Boca Raton, FL

Fu CT, Wu SC (2006) Seasonal variation of the distribution of PCBs in sediments and biota in a PCB-contaminated estuary. Chemosphere 62:1786-1794

Giesy JP, Kannan K (1998) Dioxin-like and non-dioxin-like toxic effects of polychlorinated biphenyls (PCBs): implications for risk assessment. Crit Rev Toxicol 28:511-569

Halsall CJ, Lee RGM, Coleman PJ, Burnett V, Hardingjones P, Jones KC (1995) PCBs in UK urban air. Environ Sci Technol 29:2368-2376

Han WL, Feng JL, Gu ZP, Wu MH, Sheng GY, Fu JM (2010) Polychlorinated biphenyls in the atmosphere of Taizhou, a major e-waste dismantling area in China. J Environ Sci (China) 22(4):589-597

He MC, Sun Y, Li XR, Yang ZF (2006) Distribution patterns of nitrobenzenes and polychlorinated biphenyls in water, suspended particulate matter and sediment from mid- and down-stream of the Yellow River (China). Chemosphere 65:365-374

Hennig B, Meerarani P, Slim R, Toborek M, Daugherty A, Silverstone AE, Robertson LW (2002) Proinflammatory properties of coplanar PCBs: in vitro and in vivo evidence. Toxicol Appl Pharmacol 181:174-183

Herrick RF, Lefkowitz DJ, Weymouth GA (2007) Soil contamination from PCB containing buildings. Environ. Health Persp 115:173-175

Iwata H, Tanabe S, Ueda K, Tatsukawa R (1995) Persistent organochlorine residues in air, water, sediments, and soils from the lake Baikal region, Russia. Environ Sci Technol 29:792-801

Jahangir AM, Yuan DX, Jiang YJ, Sun YC, Li Y, Xu X (2013) Polychlorinated biphenyls in the Nanshan Underground River, China. Chin J Geochem 22:357-366

Lammel G, Ghim YS, Grados A, Gao HW, Huhnerfuss H, Lohmann R (2007) Levels of persistent organic pollutants in air in China and over the Yellow Sea. Atmos Environ 41:452-464

Leung A, Cai ZW, Wong MH (2006) Environmental contamination from electronic waste recycling at Guiyu, southeast China. J Mater Cy Waste Manag 8:21-33

Ma J, Cheng JP, Xie HY, Hu XF, Li W, Zhang J, Yuan T, Wang WH (2007) Seasonal and spatial character of PCBs in a chemical industrial zone of Shanghai. China. Environ. Geochem Health 29:503-511

Mai BX, Zeng EY, Luo XJ, Yang QS, Zhang G, Li XD, Sheng GY, Fu JM (2005) Abundances, depositional fluxes, and homologue patterns of polychlorinated biphenyls in dated sediment cores from the Pearl River Delta, China. Environ Sci Technol 39:49-56

Menad N, Björkman B, Allain EG (1998) Combustion of plastics contained in electric and electronic scrap. Resour Conserv Recycl 24:65-85

Pearson RF, Hornbuckle KC, Eisenreich SJ, Swackhamer DL (1996) PCBs in Lake Michigan water revisited. Environ Sci Technol 30:1429-1436

Safe S (1992) Development, validation and limitations of toxic equivalency factors. Chemosphere 25:61-64

Tan Y, Li D, Song R, Lawrence D, Carpenter DO (2003) Orthosubstituted PCBs kill thymocytes. Toxicol Sci 76:328-337

Tan Y, Song R, Lawrence D, Carpenter DO (2004) Ortho-substituted but not coplanar PCBs rapidly kill cerebellar granule cells. Toxicol Sci 79:147-156

Tanabe S (1988) PCB problems in the future: foresight from current knowledge. Environ Pollut 50:5-28

US EPA (Environmental Protection Agency) (1985) Health assessment document for polychlorinated dibenzo-p-dioxin, EPA 600/8-84-014F

US EPA (Environmental Protection Agency) (1989) Risk assessment guidance for superfund. Volume I: Human health evaluation manual (Part A), EPA/540/1-89/002, Washington, DC 
US EPA (Environmental Protection Agency) (1997) Exposure Factors Handbook, EPA/600/P-95/002Fa, Washington, DC

US EPA (Environmental Protection Agency) (2005) US Environmental Protection Agency Guidelines for Carcinogen Risk Assessment, EPA/630/P-03/001F, Washington, DC

Van den Berg M, Birnbaum LS, Denison M, De Vito M, Farland W, Feeley M, Fiedler H, Hakansson H, Hanberg A, Haws L, Rose M, Safe S, Schrenk D, Tohyama C, Tritscher A, Tuomisto J, Tysklind M, Walker N, Peterson RE (2006) The 2005 World health organization reevaluation of human and mammalian toxic equivalency factors for dioxins and dioxin-like compounds. Toxicol Sci 93(2):223-241

Wang H, Wang CX, Wu WZ, Mo Z, Wang ZJ (2003) Persistent organic pollutants in water and surface sediments of Taihu Lake, China and risk assessment. Chemosphere 50:557-562

Wang DG, Yang M, Jia HL, Zhou L, Li YF (2008) Level, distributions and profiles of polychlorinated biphenyls in surface soils of Dalian, China. Chemosphere 73:38-42

Xing Y, Lu YL, Dawson RW, Shi YJ, Zhang H, Wang TY, Liu WB, Ren HC (2005) A spatial temporal assessment of pollution from PCBs in China. Chemosphere 60:731-739
Zhang ZL, Hong HS, Zhou JL, Huang J, Yu G (2003) Fate and assessment of persistent organic pollutants in water and sediment from Minjiang River Estuary, Southeast China. Chemosphere 52:1423-1430

Zhang JY, Qiu LM, He J, Liao Y, Luo YM (2007) Occurrence and congeners specific of polychlorinated biphenyls in agricultural soils from Southern Jiangsu, China. J Environ Sci (China) 19:338-342

Zhang XL, Luo YM, Teng Y, Yu YC, Wang JJ, Xu L, Li ZG (2009) Residue Characters of PCBs in Soils of Typical Polluted Areas in Yangtze River Delta Region (in Chinese). Soils 41(4):588-593

Zhou JL, Hong H, Zhang Z, Maskaoui K, Chen W (2000) Multiphase distribution of organic micropollutants in Xiamen Harbor, China. Water Res 34(7):2132-2150

Zhou JL, Maskaoui K, Qiu YW, Hong HS, Wang ZD (2001) Polychlorinated biphenyl congeners and organochlorine insecticides in the water column and sediments of Daya Bay, China. Environ Pollut 113:373-384 